\title{
Microlepidogaster dimorpha, a new species of Hypoptopomatinae (Siluriformes: Loricariidae) from the upper rio Paraná system
}

\author{
Fernanda de Oliveira Martins and Francisco Langeani
}

Microlepidogaster dimorpha, new species, is described from tributaries of rio Grande, upper rio Paraná system. Microlepidogaster dimorpha differs from M. perforatus and M. longicolla by having first dorsal-fin proximal radial attached to the neural spine of seventh vertebra, with posterior portion contacting also the eighth centrum ( $v s$. first dorsal-fin proximal radial attached to the neural spine of eighth or ninth vertebra in M. perforatus, and to the neural spine of tenth or eleventh vertebra in M. longicolla); 29-30 vertebrae (vs. 31 in M.perforatus and 31-33 in M. longicolla); 18-21 mid-dorsal plates ( $v s .9-13$ in M. perforatus, and 13-17 in M. longicolla); deeper caudal peduncle (10.0-11.4\% in SL vs. 7.7-8.5\% in M. perforatus, and 5.4-7.3\% in M. longicolla); greater distance between dorsal-fin origin and anal-fin insertion (19.4-23.8\% in SL vs. $16.4-18.8 \%$ in $M$. perforatus, and $14.7-16.2 \%$ in M. longicolla); and nostril width markedly wider in males than in females (vs. approximately equivalent in size for both sexes, slightly wider in males than in females in M. perforatus, and equivalent in size for both sexes in M. longicolla). Microlepidogaster dimorpha also differs from M. perforatus by presence of the iris operculum ( $v s$. absence); median plate series complete to caudal peduncle end ( $v s$. median plate series truncated, with last two plates of dorsal and ventral series contacting in midline); greater head depth (43.4-53.1\% vs. 40.7-42.3\% in HL); greater orbital diameter (13.6-18.5\% vs. 11.1-13.5\% in HL); pelvic-fin first unbranched ray longer in males than in females (vs. equivalent in size in both sexes); and supraneural without paired anterior processes ( $v s$. processes present). Additionally, M. dimorpha can be distinguished from $M$. longicolla by having anterior margin of snout with a paired rostral plate ( $v s$. snout with small plates, naked in the anterior margin); by pectoral-fin axillary slit present, even in adult specimens ( $v s$. pectoral-fin axillary slit present only in juvenile specimens); longer pectoral-fin unbranched ray (20.0-23.8\% vs. $13.4-16.2 \%$ in SL in M. longicolla).

Microlepidogaster dimorpha, espécie nova, é descrita de tributários do rio Grande, drenagem do alto rio Paraná. Microlepidogaster dimorpha difere de M. perforatus e M. longicolla por apresentar o primeiro radial proximal da nadadeira dorsal contactando o espinho neural da sétima vértebra, com sua porção posterior contactando também o oitavo centro vertebral (vs. primeiro radial proximal contactando o espinho neural da oitava ou nona vértebra em $M$. perforatus e o espinho neural da décima ou décima primeira vértebra em M. longicolla); 29-30 vértebras (vs. $31 \mathrm{em} \mathrm{M.} \mathrm{perforatus;} \mathrm{e} \mathrm{31-33} \mathrm{em}$ M. longicolla); 18-21 placas médio-dorsais (vs. 9-13 em M. perforatus, e 13-17 em M. longicolla); pedúnculo caudal alto (10,011,4\% no comprimento-padrão vs. 7,7-8,5\% em M. perforatus e 5,4-7,3\% em M. longicolla); distância entre a origem da nadadeira dorsal e a inserção da nadadeira anal 19,4-23,8\% no comprimento-padrão ( $v s .16,4-18,8 \%$ em M. perforatus e 14,7$16,2 \%$ in M. longicolla); e narina nitidamente mais larga em machos do que em fêmeas ( $v s$. aproximadamente equivalentes em tamanho em ambos os sexos, ligeiramente mais larga em machos em M. perforatus, e equivalentes em tamanho em ambos os sexos em M. longicolla). Microlepidogaster dimorpha também difere de M. perforatus pelo opérculo da íris presente ( $v s$. ausente); série de placas mediana completa até o fim do pedúnculo caudal (vs. série de placas mediana truncada, as duas últimas placas das séries dorsal e ventral em contato); altura da cabeça 43,4-53,1\% no comprimento da cabeça ( $v s .40,7-42,3 \%$ ); maior diâmetro orbital, 13,6-18,5\% no comprimento da cabeça (vs. 11,1-13,5\%); raio indiviso da nadadeira pélvica maior em machos do que nas fêmeas ( $v s$. equivalente em ambos os sexos); e ausência de processos anteriores pareados no supraneural (vs. presença). Adicionalmente, M. dimorpha pode ser distinguido de M. longicolla por apresentar a margem anterior do focinho com uma placa rostral pareada ( $v s$. focinho com pequenas placas, nu na margem anterior); fenda axilar da nadadeira peitoral presente, inclusive em espécimes adultos ( $v s$. fenda axilar da nadadeira peitoral presente apenas em espécimes juvenis); raio indiviso da nadadeira peitoral longo (20,0-23,8\% no comprimento-padrão vs. $13,4-16,2 \%$ em M. longicolla).

Key words: Cascudinhos, Microlepidogaster perforatus, Neotropical Region, Sexual dimorphism, Taxonomy.

UNESP - Universidade Estadual Paulista, Instituto de Biociências, Letras e Ciência Exatas, Departamento de Zoologia e Botânica, Laboratório de Ictiologia. Rua Cristóvão Colombo, 2265, 15054-000 São José do Rio Preto, SP, Brazil.fernanda_martins2@hotmail.com 


\section{Introduction}

Microlepidogaster, type species Microlepidogaster perforatus, was described by Eigenmann \& Eigenmann (1889) as related to Otocinclus Cope, differing from that by having the ventral surface of body covered with minute granular plates, dorsal fin inserted far posterior to the ventrals, and temporal plate perforate. However, these characters are not unequivocal to diagnose Microlepidogaster from other hypoptopomatines, and in consequence, additional species were described inside the genus, as well as transferred from other Hypoptopomatinae genera to Microlepidogaster.

Phylogenetic analyses performed by Schaefer (1991, 1997, 1998) allowed a reevaluation and rearrangement of the generic composition of the Hypoptopomatinae. As a consequence, Schaefer (1998) restricted Microlepidogaster to its type species, M. perforatus, diagnosing it by the following autapomorphies: levator crest absent from the hyomandibula; dorsal fin position shifted posteriorly (first dorsal-fin proximal radial attached to the neural spine of ninth vertebra); supraneural with paired anterior processes; median plate series truncated; a median rostral plate present.

During samplings in the upper rio Paraná system, a new Microlepidogaster was collected in headwaters of the rio Grande. This contribution aims to describe this new species, based on the possession of some of the derived traits proposed by Schaefer (1998). We also make comments about the current diagnosis for the genus, and describe a sexual dimorphism never reported to Hypoptopomatinae.

\section{Material and Methods}

Measurements were made with digital calipers, point-topoint, on the left side of the specimens and to the nearest 0.1 $\mathrm{mm}$, following Boeseman (1968), with modifications of Armbruster \& Page (1996), and Ribeiro et al. (2005). Additional measurements were included: prepectoral length (from snout tip to pectoral-fin origin); prepelvic length (from snout tip to pelvic-fin origin); head width (width in opercle region); dorsal to anal-fin length (from dorsal-fin origin to anal-fin origin); prenasal length (from snout tip to anterior edge of nostril); internasal length (distance between inner edges); nostril width (from outer to inner edge); suborbital depth (from inferior edge of eye to ventral margin of head). Plate counts and nomenclature followed Schaefer (1997). Plates were counted from both sides in cleared and stained (c\&s) specimens, prepared according to Taylor \& van Dyke (1985). Vertebrae counts included five from the Weberian apparatus, and the compound caudal centrum was counted as a single element. Dorsal-fin ray counts included spinelet as first unbranched ray. Morphometric data were expressed as percents of standard length (SL), except for measurements of the head, which were given as percents of head length (HL). Sex determination was made upon dissection of mature specimens. Museum abbreviations for specimens examined are listed in Fricke \& Eschmeyer (2010), with the addition of the fish collection of the Museu de Zoologia, Universidade Estadual de Londrina, Paraná State, Brazil (MZUEL).

\section{Results \\ Microlepidogaster dimorpha, new species Figs. 1, 2b, and 3}

Holotype. DZSJRP 10543, 37.6 mm SL, female, Brazil, Minas Gerais, Uberaba, riacho Grotão at Fazenda Nossa Senhora da Abadia, unpaved road at BR-262, rio Grande drainage, 19² $41^{\prime} 31^{\prime \prime S}$ $47^{\circ} 42^{\prime} 57^{\prime}$ 'W, 12 May 2007, L. G. G. Silveira \& F. Langeani.

Paratypes. All from Brazil, Minas Gerais, rio Grande drainage, Uberaba. DZSJRP 5564, 11, 25.8-35.1 mm SL (10, 25.8-35.1 mm SL), road Uberaba-Almeida Campos and Nova Ponte, rio Uberaba, 19³9'40”S 47049'23”'W, 21 May 2003, J. P. Serra, F. Langeani, F. R. Carvalho \& D. O. Tavares; DZSJRP 8750, 19, 2 c\&s, 19.8-37.7 mm SL (14, 25.0-37.7 mm SL), MCP 45866, 2, 26.7-30.8 mm SL, MNRJ 37848, 2, 25.5-26.8 mm SL, MZUSP 107585, 2, 27.8-30.2 $\mathrm{mm} \mathrm{SL}$, same locality of holotype, 8 Sep 2006,F. Langeani, F. R. Carvalho, C. P. Ferreira, H. F. Chaves \& F. O. Martin; DZSJRP $12332,17,2$ c\&s, 20.3-34.1 mm SL (6, 29.7-37.6 mm SL), LBP 4854, 4, 29.8-32.9 mm SL, MCP 41912, 4, 28.7-34.0 mm SL, collected with holotype.

Diagnosis. Microlepidogaster dimorpha differs from $M$. perforatus (Tables 3 and 4) and M. longicolla Calegari \& Reis, 2010 by having first dorsal-fin proximal radial attached to the neural spine of seventh vertebra, with posterior portion contacting also the eighth centrum ( $v s$. first dorsal-fin proximal radial attached to the neural spine of eighth or ninth vertebra in M.perforatus, and to the neural spine of tenth or eleventh vertebra in $M$. longicolla); 29-30 vertebrae (vs. 31 in $M$. perforatus; and 31-33 in M. longicolla); 18-21 mid-dorsal plates (vs. 9-13 in M.perforatus, and 13-17 in M. longicolla); deeper caudal peduncle $(10.0-11.4 \%$ in SL vs. $7.7-8.5 \%$ in $M$. perforatus, and 5.4-7.3\% in M. longicolla); greater distance between dorsal-fin origin and anal-fin insertion (19.4-23.8\% in SL vs. $16.4-18.8 \%$ in M. perforatus, and $14.7-16.2 \%$ in $M$. longicolla); and nostril width markedly wider in males than in females ( $v s$. approximately equivalent in size for both sexes, slightly wider in males than in females in M. perforatus, and equivalent in size for both sexes in M. longicolla). Microlepidogaster dimorpha also differs from $M$. perforatus by having the iris operculum ( $v s$. absent); median plate series complete to caudal peduncle end ( $v s$. median plate series truncated, with last two plates of dorsal and ventral series contacting in midline); greater head depth (43.4-53.1\% vs. 40.7 $42.3 \%$ in HL); greater orbital diameter (13.6-18.5\% vs. 11.1 $13.5 \%$ in HL); pelvic-fin first unbranched ray longer in males than in females ( $v s$. equivalent in size in both sexes); and supraneural without paired anterior processes (vs. processes present). Additionally, $M$. dimorpha can be distinguished from $M$. longicolla by having anterior margin of snout with a paired rostral plate ( $v s$. snout with small plates, naked in the anterior margin); pectoral-fin axillary slit present, even in adult specimens ( $v s$. pectoral-fin axillary slit present only in juvenile 


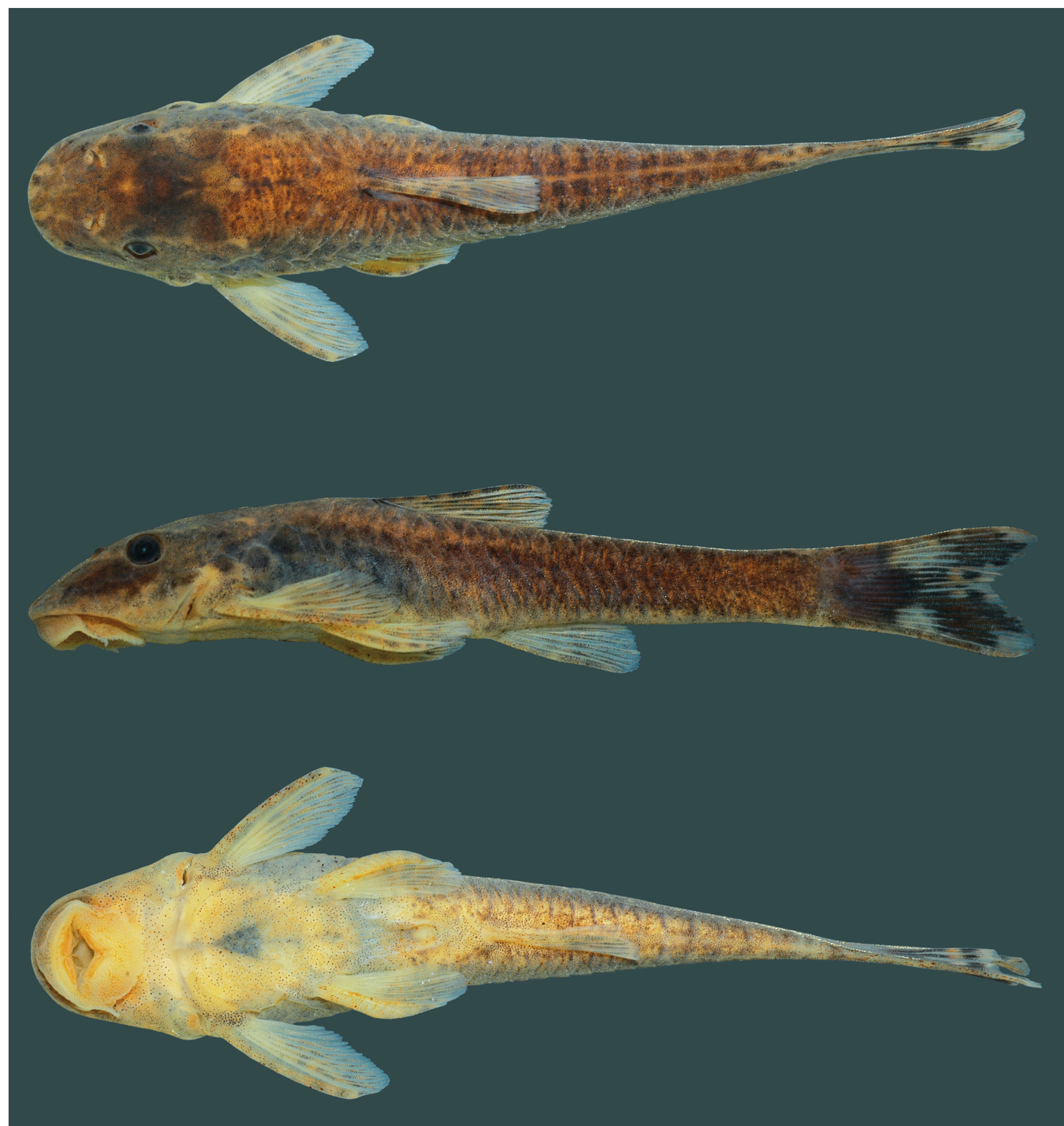

Fig. 1. Microlepidogaster dimorpha, holotype, DZSJRP 10543, 37.6 mm SL, female, riacho Grotão at Fazenda Nossa Senhora da Abadia, Uberaba, Minas Gerais, Brazil.

specimens); longer pectoral-fin unbranched ray (20.0-23.8\% in SL vs. 13.4-16.2\% in M. longicolla).

Description. Morphometric and meristic data are given in Tables 1-2. Dorsal body profile convex from tip of snout to dorsal-fin origin; descending posteriorly at dorsal-fin base; almost straight from end of dorsal-fin base to caudal-fin origin. Ventral body profile almost straight; ascending posteriorly from anus to end of anal-fin base; straight to caudal-fin origin. Greatest body depth at dorsal-fin origin. Greatest body width at opercular region, gradually tapering toward snout and caudal fin. Head profile rounded in dorsal view; rostral margins with thin plates, not deflected ventrally; anterior tip of rostrum with a median pair of plates; odontodes at anterior margin of snout small and leaf-shaped (Fig. 2b), some with edge slightly rounded. Odontodes equal in size 
Table 1. Morphometric data for Microlepidogaster dimorpha. Holotype $(\mathrm{H})$ and 30 paratypes, 16 females, and 14 males (DZSJRP 5564, 8750, 12332; MCP 45866; MNRJ 37848; MZUSP 107585); range includes holotype. $\mathrm{SD}=$ Standard deviation.

\begin{tabular}{|c|c|c|c|c|c|}
\hline Character & $\mathrm{H}$ & Minimum & Maximum & Mean & $\mathrm{SD}$ \\
\hline Standard length (mm) & 37.6 & 25.0 & 37.7 & - & - \\
\hline \multicolumn{6}{|c|}{ Percents of Standard length } \\
\hline Predorsal length & 44.8 & 42.3 & 50.0 & 45.3 & 1.5 \\
\hline Preanal length & 57.1 & 53.1 & 62.2 & 58.3 & 1.6 \\
\hline Prepectoral length & 25.4 & 23.4 & 29.9 & 26.4 & 1.2 \\
\hline Prepelvic length & 36.6 & 33.8 & 42.6 & 37.2 & 1.8 \\
\hline Postanal length & 36.9 & 33.0 & 38.5 & 35.7 & 1.4 \\
\hline Thoracic length & 16.1 & 13.8 & 18.5 & 15.9 & 1.1 \\
\hline Abdominal length & 21.8 & 19.5 & 23.6 & 21.8 & 1.0 \\
\hline Caudal-peduncle depth & 10.3 & 10.0 & 11.4 & 10.7 & 0.4 \\
\hline Head length & 30.4 & 29.8 & 37.2 & 32.3 & 1.4 \\
\hline Head width & 22.5 & 21.4 & 24.5 & 22.7 & 0.8 \\
\hline Head depth & 14.4 & 14.1 & 16.7 & 15.2 & 0.7 \\
\hline Base of dorsal-fin length & 12.9 & 10.6 & 14.3 & 12.6 & 0.8 \\
\hline Folded dorsal-fin length & 22.4 & 20.3 & 25.2 & 23.3 & 1.1 \\
\hline Pectoral-fin unbranched ray length & 21.6 & 20.0 & 23.8 & 22.1 & 1.0 \\
\hline Pelvic-fin unbranched ray length & 16.4 & 15.4 & 20.9 & 18.3 & 1.8 \\
\hline Males & - & 18.3 & 20.9 & 19.9 & 0.8 \\
\hline Females & 16.4 & 15.4 & 18.2 & 16.9 & 1.0 \\
\hline Snout-opercle length & 24.9 & 23.8 & 28.8 & 25.7 & 0.9 \\
\hline Dorsal to anal-fin length & 20.5 & 19.4 & 23.8 & 21.5 & 1.0 \\
\hline \multicolumn{6}{|c|}{ Percents of Head length } \\
\hline Head width & 74.1 & 62.7 & 75.9 & 70.3 & 2.9 \\
\hline Head depth & 47.5 & 43.3 & 53.1 & 47.2 & 2.2 \\
\hline Snout length & 51.4 & 48.3 & 54.4 & 51.1 & 1.5 \\
\hline Orbital diameter & 17.3 & 13.6 & 18.5 & 16.5 & 1.3 \\
\hline Interorbital length & 44.1 & 38.8 & 44.8 & 42.2 & 1.7 \\
\hline Barbel length & 4.5 & 4.0 & 8.1 & 5.5 & 1.0 \\
\hline Prenasal length & 34.5 & 28.0 & 35.8 & 32.4 & 1.9 \\
\hline Internasal length & 16.3 & 9.2 & 17.0 & 12.8 & 1.8 \\
\hline Nostril width & 7.9 & 7.9 & 15.4 & 11.2 & 2.4 \\
\hline Males & - & 11.5 & 15.4 & 13.5 & 1.2 \\
\hline Females & 7.9 & 7.9 & 10.3 & 9.2 & 0.7 \\
\hline Suborbital depth & 24.5 & 20.4 & 24.9 & 23.2 & 1.2 \\
\hline
\end{tabular}

and uniformly distributed, not forming rows, on head and body. Eyes small, dorsolaterally placed, not visible from ventral view. Iris operculum present. Infraorbital canal entering infraorbital series via compound pterotic.
Compound pterotic roughly quadrangular in shape, without elongate posterior extension; small to median roundish perforations on posteroventral margin. Caudal peduncle slightly flattened dorsally and ventrally, somewhat rectangular in transverse section.

Abdomen partially covered by small plates, approximately same size of pupil, irregularly arranged. Body entirely covered with bone plates, except on ventral part of head, region overlying opening of swim bladder capsule, and around anus and pelvic-fin origin.

Lips roundish, papillose; lower lip larger than upper lip; larger papillae near oral opening. Maxillary barbel reduced, free from oral disk. Teeth slender, bifid; median cusp larger and rounded, lateral smaller and pointed. Premaxillary teeth $15-28($ mode $=23,24)$. Dentary teeth 12-25 $($ mode $=21)$. Premaxillary and dentary accessory teeth absent.

Dorsal fin ii, 6-7 (mode $=7)$, originating approximately at vertical through end of pelvic-fin base; its length surpassing anal-fin origin; spinelet small, somewhat rectangular, anterior and posterior margins slightly straight; locking mechanism non-functional. Anterior portion of compound supraneuralfirst dorsal-fin proximal radial contacting neural spine of $7^{\text {th }}$ vertebra; posteriorly contacting the $8^{\text {th }}$ vertebra. Pectoral fin i, 6-7 (mode $=6$ ); originating immediately behind opercular opening and surpassing pelvic-fin origin. Cleithrum and coracoid exposed and supporting odontodes laterally, covered by skin medially. Arrector fossae partially enclosed by ventral lamina of coracoid; opening extending laterally approximately halfway towards pectoral-fin base. Pectoral axillary slit present, about 2.5 times in orbital diameter. Pelvic fin i, 5-6 (mode $=5)$; reaching anal-fin origin in males when depressed. Anal fin i, 4-6 (mode $=5)$; originating at vertical through end of dorsal-fin base. Caudal fin i, 14, i; lobes equal in size; 5-6 $($ mode $=5)$ dorsal and 4-5 $($ mode $=5)$ ventral procurrent rays. Adipose fin and azygous plates absent. Median lateral plate series 24-27 plates, complete from compound pterotic to caudal-fin base. Vertebrae 29-30 (mode $=29)$.

Table 2. Frequency distribution of meristic data for Microlepidogaster dimorpha. Rays and teeth counts were made for holotype (DZSJRP 10543) and for 30 paratypes (DZSJRP 5564, 8750, 12332; MCP 45866; MNRJ 37848; MZUSP 107585). Plates (counted in both sides whenever possible), procurrent rays, and vertebrae counts were made for $4 \mathrm{c} \& s$ paratypes (DZSJRP $8750,12332)$.

\begin{tabular}{|c|c|c|c|}
\hline Character & Frequency distribution & Range & Mode \\
\hline Dorsal plates & $24(3) ; 25(4)$ & $24-25$ & 25 \\
\hline Mid-dorsal plates & $18(1) ; 19(3) ; 20(1) ; 21(1)$ & $18-21$ & 19 \\
\hline Median plates & $24(1) ; 25(2) ; 26(1) ; 27(1)$ & $24-27$ & 25 \\
\hline Mid-ventral plates & $17(1) ; 18(2) ; 19(3) ; 20(1)$ & $17-20$ & 19 \\
\hline Ventral plates & $20(1) ; 21(1) ; 22(4) ; 23(1)$ & $20-23$ & 22 \\
\hline Premaxillary teeth & $15(1) ; 16(1) ; 17(2) ; 18(5) ; 19(7) ; 20(4) ; 21(3) ; 22(9) ; 23(10) ; 24(10) ; 25(2) ; 26(1) ; 27(4) ; 28(1)$ & $15-28$ & $23-24$ \\
\hline Dentary teeth & $12(1) ; 14(3) ; 15(4) ; 16(7) ; 17(5) ; 18(6) ; 19(6) ; 20(5) ; 21(9) ; 22(5) ; 23(2) ; 24(2) ; 25(1)$ & $12-25$ & 21 \\
\hline Dorsal-fin branched rays & $6(1) ; 7(29)$ & $6-7$ & 7 \\
\hline Pectoral-fin branched rays & $6(29) ; 7(1)$ & $6-7$ & 6 \\
\hline Pelvic-fin branched rays & $5(29) ; 6(1)$ & $5-6$ & 5 \\
\hline Anal-fin branched rays & $4(1) ; 5(28) ; 6(1)$ & $4-6$ & 5 \\
\hline Caudal-fin branched rays & $14(30)$ & - & 14 \\
\hline Dorsal procurrent rays & $5(2) ; 6(1)$ & $5-6$ & 5 \\
\hline Ventral procurrent rays & $4(1) ; 5(2)$ & $4-5$ & 5 \\
\hline Vertebrae & $29(3) ; 30(1)$ & $29-30$ & 29 \\
\hline
\end{tabular}


Table 3. Morphometric data for Microlepidogaster perforatus (MNRJ 31886, MZUSP 10216, 10217; $\mathrm{n}=5$ ). SD = Standard deviation.

\begin{tabular}{lcccc}
\hline Character & Minimum & Maximum & Mean & SD \\
\hline Standard length (mm) & 29.93 & 32.76 & - & - \\
& Percents of Standard length & & & \\
Predorsal length & 45.5 & 47.8 & 46.7 & 1.0 \\
Preanal length & 54.8 & 58.4 & 57.2 & 1.4 \\
Prepectoral length & 25.5 & 27.5 & 26.5 & 0.8 \\
Prepelvic length & 35.2 & 36.6 & 35.9 & 0.6 \\
Postanal length & 35.5 & 39.5 & 37.1 & 1.6 \\
Thoracic length & 13.6 & 15.5 & 14.4 & 0.8 \\
Abdominal length & 19.3 & 23.2 & 20.8 & 1.6 \\
Caudal-peduncle depth & 7.7 & 8.5 & 8.1 & 0.3 \\
Head lenght & 33.2 & 34.7 & 34.1 & 0.6 \\
Head width & 21.0 & 23.2 & 22.4 & 0.9 \\
Head depth & 13.9 & 14.4 & 14.2 & 0.2 \\
Base of dorsal-fin length & 11.2 & 12.6 & 11.6 & 0.5 \\
Folded dorsal-fin length & 21.0 & 22.8 & 22.1 & 0.7 \\
Pectoral-fin & 19.5 & 20.7 & 20.1 & 0.4 \\
unbranched ray length & 15.0 & 19.1 & 16.6 & 1.7 \\
Pelvic-fin unbranched ray length & 24.1 & 26.5 & 25.7 & 0.9 \\
Snout-opercle length & 16.7 & 18.8 & 17.5 & 0.8 \\
Dorsal to anal-fin length & Percents of Head length & & & \\
& 60.6 & 68.0 & 65.6 & 3.0 \\
Head width & 40.7 & 42.3 & 41.6 & 0.7 \\
Head depth & 47.5 & 51.9 & 49.2 & 1.9 \\
Snout length & 11.1 & 13.5 & 12.6 & 1.0 \\
Orbital diameter & 36.7 & 41.2 & 39.3 & 1.9 \\
Interorbital length & 6.0 & 8.7 & 7.1 & 1.1 \\
Barbel length & 32.2 & 35.3 & 33.6 & 1.4 \\
Prenasal length & 10.0 & 12.7 & 11.6 & 1.0 \\
Internasal length & 11.2 & 12.4 & 11.9 & 0.62 \\
Nostril width & 20.4 & 21.7 & 21.0 & 0.5 \\
Suborbital depth & & & & \\
\hline & & &
\end{tabular}

Color in alcohol. Most specimens with a dark brown color along the dorsal portion of head and dorsal midline of body. Four dorsal dark saddles, not extending laterally, inconspicuous in adults. Longitudinal clear stripe from dorsal portion of snout to nostril. Lateroventral portion of head unpigmented. Lateral portion of body brown; an inconspicuous dark longitudinal stripe at median plate series, extending from compound pterotic to vertical through end of depressed dorsal fin. Ventral surface of body light brown. Dorsal, anal, pectoral, and pelvic-fins membrane hyaline; all rays with transverse dark bands. Caudal fin mostly dark brown, except for hyaline portions at lobe tips, middle-rays extremities, and a circular area in the middle of each lobe.

Sexual dimorphism. Males with a conspicuous urogenital papillae immediately posterior to anus ( $v s$. absent in females); expanded flap of skin on dorsal surface of the first pelvic-fin ray and branched rays, less developed in the latter ( $v s$. absent in females); pelvic fin reaching anal-fin origin, its first unbranched ray 18.3-20.9\% in SL ( $v$ s. pelvic fin not reaching anal-fin origin, its first unbranched ray 15.4-18.2\% in SL in females); males, usually with fewer teeth than females, probably related with their smaller size; males with wider nostril width (11.5-15.4\% of HL vs. 7.9-10.3\% in females), with an anterior single row of 4 to 6 small odontodes
Table 4. Frequency distribution of meristics for Microlepidogaster perforatus. Plates (counted in both sides whenever possible), procurrent rays were made for 3 specimens, and vertebrae counts were made for $1 \mathrm{c} \&$ s specimen (MNRJ 31886; MZUSP 10216, 10217).

\begin{tabular}{lccc}
\hline Character & Frequency distribution & Range & Mode \\
\hline Dorsal plates & $25(1) ; 26(4) ; 27(1)$ & $25-27$ & 26 \\
Mid-dorsal plates & $9(1) ; 10(2) ; 11(1) ; 12(1) ; 13(1)$ & $9-13$ & 10 \\
Median plates & $21(2) ; 23(2) ; 25(2)$ & $21-25$ & $21 / 23 / 25$ \\
Mid-ventral plates & $19(3) ; 20(3)$ & $19-20$ & $19 / 20$ \\
Ventral plates & $20(2), 21(2) ; 22(2)$ & $20-2220 / 21 / 22$ \\
Premaxillary teeth & $16(4) ; 17(4) ; 18(1) ; 19(1)$ & $16-19$ & $16 / 17$ \\
Dentary teeth & $11(1) ; 12(2) ; 13(4) ; 14(1) ; 15(2)$ & $11-15$ & 13 \\
Dorsal-fin branched rays & $7(5)$ & - & 7 \\
Pectoral-fin branched rays & $5(1) ; 6(4)$ & $5-6$ & 6 \\
Pelvic-fin branched rays & $5(5)$ & - & 5 \\
Anal-fin branched rays & $5(5)$ & - & 5 \\
Caudal-fin branched rays & $14(5)$ & - & 14 \\
Dorsal procurrent rays & $4(1) ; 5(2)$ & $4-5$ & 5 \\
Ventral procurrent rays & $4(3)$ & - & 4 \\
Vertebrae & 31 & - & 31 \\
\hline
\end{tabular}

associated with skin of the anterior portion of anterior nostril (vs. absent in females; Fig. 3).

Distribution. The species is known from rio Uberaba and riacho Grotão, both tributaries of the rio Grande, upper rio Paraná system, Minas Gerais, Brazil (Fig. 4).

Etymology. Epithet dimorpha from the Greek di, two, double, and morphe, form, in allusion to the accentuated sexual dimorphism presented by the species. A feminine adjective.

\section{Discussion}

According to Schaefer (1998), Microlepidogaster perforatus is diagnosed by five autapomorphies: levator crest absent (character 14:1); neural spine of seventh vertebra not contacting the nuchal plate, and first dorsal-fin proximal radial articulating with the neural spine of the ninth vertebra (26:1); supraneural with paired anterior processes (28: 1); median plate series truncated (33:1); median rostral plate, or paired plate, present (34:1).

Recently, a new species was proposed, M. longicolla Calegari \& Reis, 2010, which was included in the Microlepidogaster by sharing with M. perforatus the dorsal fin placed posteriorly, with the first pterygiophore articulating with the neural spine of the tenth or eleventh vertebral centrum (with the eighth or ninth in $M$. perforatus). Now, Microlepidogaster dimorpha was included in the genus by sharing with $M$. perforatus two other apomorphic character states of Schaefer (1998): levator crest extremely reduced in size and median rostral plate paired.

Schaefer (1998) considered the levator crest absent in $M$. perforatus; however Calegari \& Reis (2010) identified a low crest in that species. Indeed, M. perforatus presents an extremely reduced crest in the hyomandibula, which is shared with M. dimorpha ( $v s$. more developed in M. longicolla, as in the plesiomorphic state). 
a

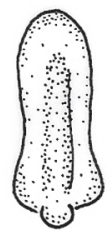

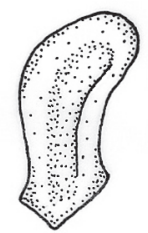

$\mathrm{b}$

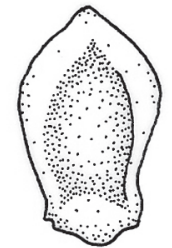

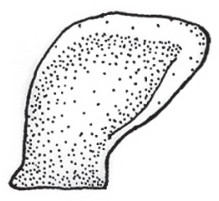
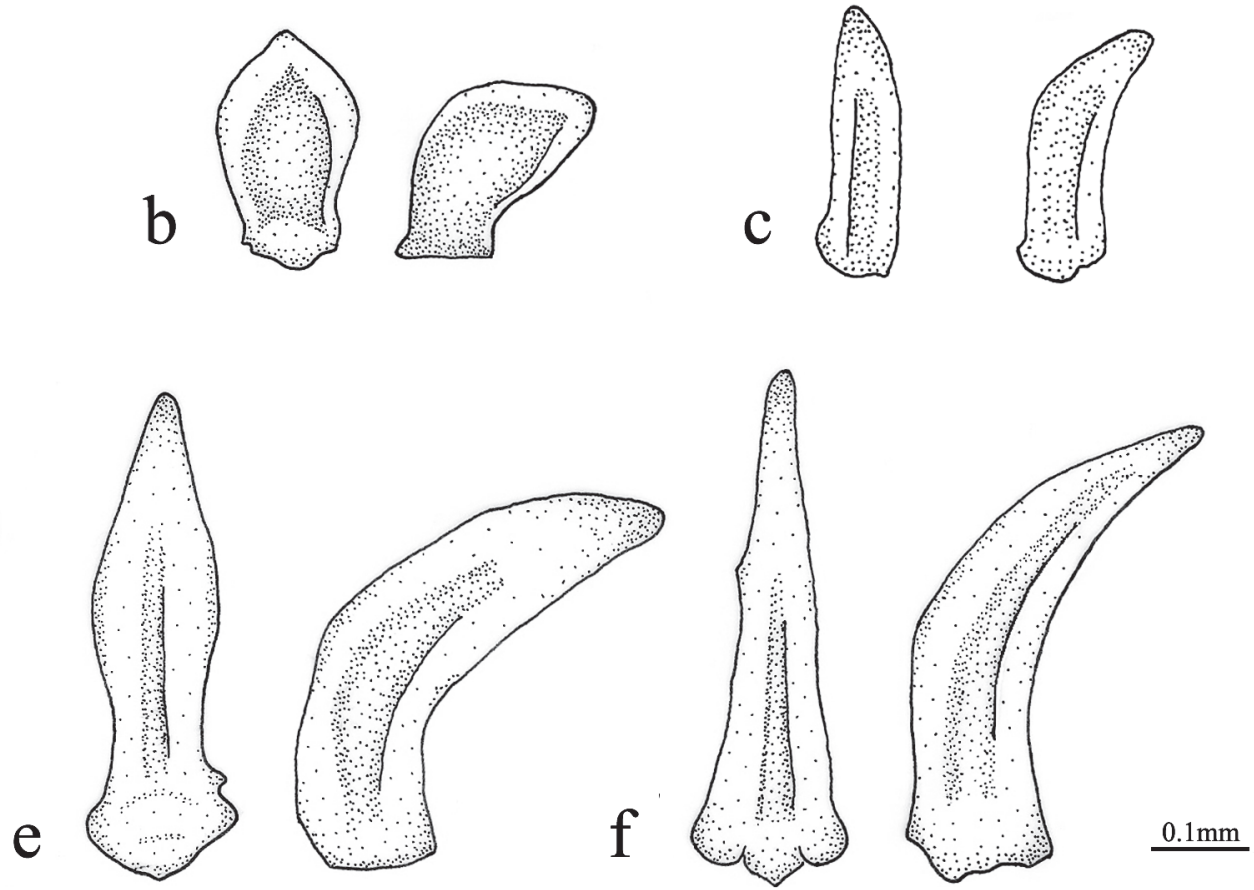

Fig. 2. Range of size and shape of odontodes on dorsal tip of rostrum. a. Microlepidogaster perforatus, MNRJ 31886, male, 30.6 mm SL. b. Microlepidogaster dimorpha, male, DZSJRP 8750, paratype, $29.3 \mathrm{~mm}$ SL. c. Microlepidogaster longicolla, female, DZSJRP 12435, paratype, $39.7 \mathrm{~mm}$ SL. d. Pseudotocinclus tietensis, DZSJRP 6940, female, $54.7 \mathrm{~mm}$ SL. e. Epactionotus bilineatus, DZSJRP 11358, female, $32.9 \mathrm{~mm}$ SL. f. Hisonotus depressicauda, DZSJRP 11422, female, $32.2 \mathrm{~mm}$ SL. Ventral (left) and lateral (right) views.

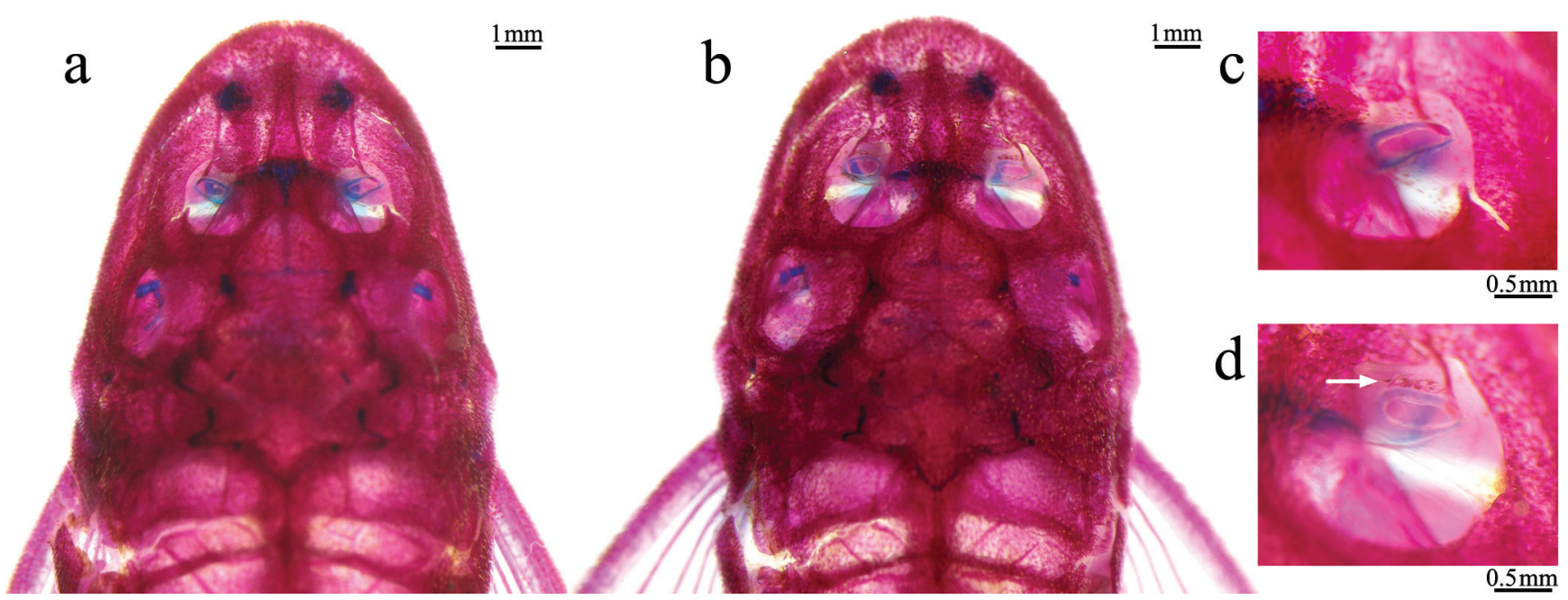

Fig. 3. Dorsal view of the skull of Microlepidogaster dimorpha, showing the sexual dimorphism in nostril morphology. a, c. DZSJRP 12332, paratype, female, $30.8 \mathrm{~mm}$ SL. b, d. DZSJRP 12332, paratype, male, $30.4 \mathrm{~mm}$ SL. Arrow indicates the single row of odontodes in front of naris of male.

The anterior portion of the first dorsal-fin proximal radial in $M$. perforatus contacts the neural spine of the eighth (our analysis and Calegari \& Reis, 2010) or ninth vertebrae (Schaefer, 1998). In M. dimorpha, the first dorsal-fin proximal radial contacts the neural spine of the seventh vertebra, but also the dorsal portion of the eighth, and in M. longicolla the first dorsal-fin proximal radial contacts the neural spine of the tenth or eleventh vertebra. The dorsal fin shifted posteriorly relative to the parieto-supra-occipital, however, is not exclusive for $M$. perforatus and $M$. longicolla, being also present in the species of Epactionotus Reis \& Schaefer, 1998 (eighth vertebra), Parotocinclus jumbo Britski \& Garavello, 


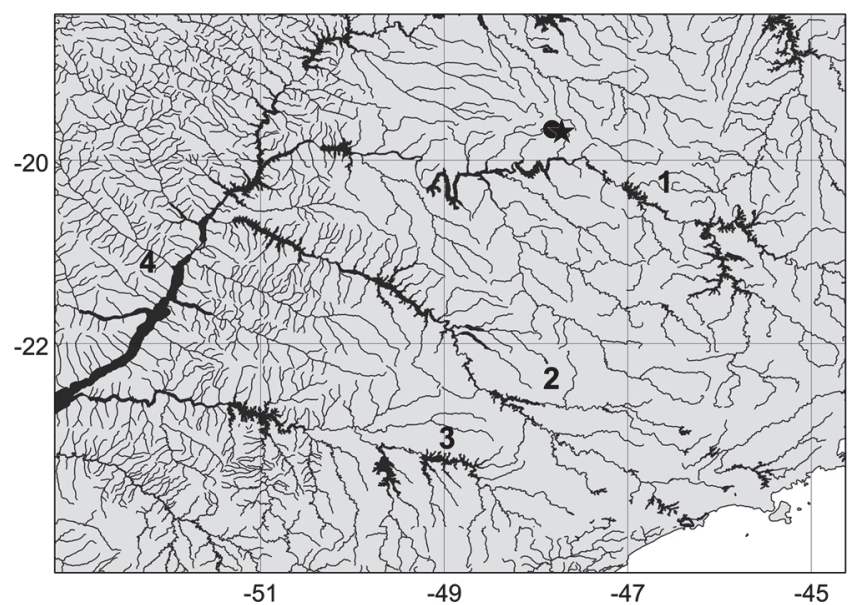

Fig. 4. Southeastern Brazil showing geographic distribution of Microlepidogaster dimorpha in rio Grande drainage (1 - rio Grande; 2 - rio Tietê; 3 - rio Paranapanema; 4 - rio Paraná). Star designates the type locality.

2002 (eighth, Bárbara Calegari, pers. commun.), and Rhinolekos britskii (ninth), R. garavelloi, and R. schaeferi (tenth) (Martins \& Langeani, 2011). Therefore, the posterior insertion of the dorsal fin is likely to have appeared independently several times within hypoptopomatines. In consequence, we think this feature deserves a more exhaustive analysis in order to understand its occurrence within the Hypoptopomatinae.

Microlepidogaster perforatus possesses two other autapomorphies absent in $M$. dimorpha and $M$. longicolla: the supraneural with a paired anterior processes, and the median plate series truncated posteriorly, with the absence of the last one or two plates of the median series, such that the last one or two plates of the dorsal and ventral series contact each other in the midline.

Furthermore, in $M$. perforatus and $M$. dimorpha the most anterior plates limiting the snout, mainly the median paired rostral plate (absent in M. longicolla), bear peculiar small rounded leaf-shaped odontodes, sometimes with a slight median projection (Fig. 2a-b). These odontodes are very different from the spine-like ones present in other members of the subfamily (Fig. 2c-f), and are proposed here as an additional diagnostic character for M. perforatus and M. dimorpha. Very similar leafshaped odontodes are also present in Parotocinclus jumbo Britski \& Garavello, referred by the authors as heart-shaped odontodes (Britski \& Garavello, 2002; fig. 3).

Difference in the nostril width in M. dimorpha is a sexual dimorphism never reported before to the Hypoptopomatinae (also observed by Cristiano Moreira, pers. commun.). Males with wider nostrils were observed in other unrelated hypoptopomatins, e.g. Hisonotus francirochai (Ihering, 1928), Corumbataia cuestae Britski, 1997, Otothyropsis marapoama Ribeiro, Carvalho \& Melo, 2005, Hisonotus sp., and Pseudotothyris obtusa Britski \& Garavello, 1984. Until now, the function of these enlarged nostrils remains unclear, but we suspect that it could be related with pheromone recognition, which requires more studies.
Comparative material. Corumbataia cuestae: DZSJRP 7947, 32, 1 c\&s, rio Corumbataí affluent, Itirapina, São Paulo. Epactionotus bilineatus: DZSJRP 11358, 3, 1 c\&s, rio Maquiné, Maquiné, Rio Grande do Sul. Gymnotocinclus anosteos: UFRGS 11296, 6 of 20, 1 c\&s, rio dos Couros, rio Tocantinzinho affluent, Alto Paraíso de Goiás, Goiás. Hisonotus depressicauda: DZSJRP 11422, 6, 1 c\&s, rio Paraitinga, Salesópolis, São Paulo. Hisonotus francirochai: DZSJRP 7693, 68, 2 c\&s, rio Aguapeí affluent, Valparaíso/ Lavínia, São Paulo. Hisonotus sp.: DZSJRP 12374, 3, rio Paraíba do Sul affluent, Guaratinguetá, São Paulo. Microlepidogaster longicolla: DZSJRP 12453 (ex-MCP 23323), paratypes, 5,1 c\&s, ribeirão Santana, rio São João, Brasília, Distrito Federal; MZUEL 5001, 26, rio São Bartolomeu affluent, Brasília, Distrito Federal. Microlepidogaster perforatus: MCZ 8181, holotype, rio Carandaí, Carandaí, Minas Gerais; MNRJ 31886, 13, 2 c\&s, rio Carandaí, Carandaí, Minas Gerais; MZUSP 10216, 1; 10217, 1, rio Carandaí, Carandaí, Minas Gerais. Rhinolekos britskii: DZSJRP 12190, 17, 1 c\&s, rio Arapuca affluent, Bela Vista de Goiás, Goiás. Rhinolekos garavelloi: DZSJRP 10477, 22, 3 c\&s, rio Corumbá affluent, Caldas Novas, Goiás. Rhinolekos schaeferi: DZSJRP 12192, 3, 1 c\&s, rio Paranaíba affluent, Alexânia, Goiás. Otothyropsis marapoama: DZSJRP 9937, 12, 1 c\&s, rio Tietê affluent, Novo Horizonte, São Paulo. Pseudotocinclus tietensis: DZSJRP 6940, 2, 1 c\&s, rio Paraitinga, Salesópolis, São Paulo. Pseudotothyris obtusa: DZSJRP 3152, 6, 1 c\&s, Ribeira de Iguape affluent, Jacupiranga, São Paulo.

\section{Acknowledgements}

We are grateful to Heraldo Britski (MZUSP), Luiz R. Malabarba (UFRGS), Oscar Shibatta (MZUEL), and Paulo A. Buckup (MNRJ) for the loan of specimens. We also thank Hânia C. Godoy and Márcio C. Chiachio for helping with photographs and the staff of Laboratório de Ictiologia of UNESP - São José do Rio Preto for samplings. This study was supported by Fundação de Amparo à Pesquisa do Estado de São Paulo (FAPESP 2004/00545-8, FL; 2008/00597-9, FOM) and Conselho Nacional de Desenvolvimento Científico e Tecnológico (CNPq 306.988/2008-9, FL).

\section{Literature Cited}

Armbruster, W. J. \& L. M. Page. 1996. Redescription of Aphanotorulus (Teleostei: Loricaiidae) with description of one new species, A. ammophilus, from the Rio Orinoco basin. Copeia, 1996(2): 379-389.

Boeseman, M. 1968. The genus Hypostomus Lacépède 1803, and Surinam representatives (Siluriformes: Loricariidae). Zoologische Verhandelingen, 99: 1-89.

Britski, H. A. \& J. C. Garavello. 2002. Parotocinclus jumbo, a new species of the subfamily Hypoptopomatinae from northeastern Brazil (Ostariophysi: Loricariidae). Ichthyological Exploration of Freshwaters, 13(3): 279-288.

Calegari, B. B. \& R. E. Reis. 2010. A new species of Microlepidogaster (Siluriformes: Loricariidae: Hypoptopomatinae) from the upper rio Paraná basin, Brazil. Neotropical Ichthyology, 8(3): 625-630.

Eigenmann, C. H. \& R. S. Eigenmann. 1889. Description of new nematognathoid fishes from Brazil. West American Scientist, 6(42): 8-10. 
Fricke, R. \& W. N. Eschmeyer. 2010, A guide to fish collections in the Catalog of Fishes database. http://research.calacademy.org/ redirect?url=http://researcharchive.calacademy.org/research/ Ichthyology/catalog/collections.asp. Accessed January 28, 2010.

Gauger, M. F. W. \& P. A. Buckup. 2005. Two new species of Hypoptopomatinae from the rio Paraíba do Sul basin, with comments on the monophyly of Parotocinclus and the Otothyrini (Siluriformes: Loricariidae). Neotropical Ichthyology, 3(4): 509-518.

Martins, F. O. \& F. Langeani. 2011 (in press). Rhinolekos, a new genus with three new species of Hypoptopomatinae (Siluriformes: Loricariidae) from upper Paraná river. Neotropical Ichthyology.

Ribeiro, A. C., M. Carvalho \& A. L. A. Melo. 2005. Description and relationship of Otothyropsis marapoama, a new genus and species of Hypoptopomatinae catfish (Siluriformes: Loricariidae) from rio Tietê basin, southeastern Brazil. Neotropical Ichthyology, 3(4): 489-498.

Schaefer, S. A. 1991. Phylogenetic analysis of the loricariid subfamily Hypoptopomatinae (Pisces: Siluroidei: Loricariidae), with comments on generic diagnoses and geographic distribution. Zoological Journal of the Linnean Society, 102: 1-41.

Schaefer, S. A. 1997. The Neotropical cascudinhos: Systematics and biogeography of the Otocinclus catfishes (Siluriformes: Loricariidae). Proceedings of the Academy of Natural Sciences of Philadelphia, 148: 1-120.

Schaefer, S. A. 1998. Conflict and resolution: impact of new taxa on phylogenetic studies of the neotropical cascudinhos (Siluroidei: Loricariidae). Pp. 375-400. In: Malabarba, L. R., R. E. Reis, R. P. Vari, Z. M. S. Lucena \& C. A. S. Lucena (Eds.). Phylogeny and Classification of Neotropical Fishes. Porto Alegre, Edipucrs, 603p.

Schaefer, S. A. \& R. Provenzano. 1993. The Guyana Shield Parotocinclus: systematics, biogeography, and description of a new Venezuelan species (Siluroidei: Loricariidae). Ichthyological Exploration of Freshwaters, 4(1): 39-56.

Taylor, W. R. \& G. C. van Dike. 1985. Revised procedures for staining and clearing small fishes and other vertebrates for bone and cartilage study. Cybium, 9(2): 107-119.

Accepted December 9, 2010

Published March 31, 2011 